Gdańsk

\title{
STRATEGIE NAUCZANIA FILOZOFII
}

Streszczenie: W Polskich mediach, nawet tych ambitnych, brak jest filozoficznych analiz oraz komentarzy do życia intelektualnego i politycznego. Co więcej, brak również zapotrzebowania na nie. Ta konstatacja skłania do poszukiwania przyczyn. Jedną z głównych autor widzi w - oczyszczonym z odniesień do rzeczywistości społeczno-kulturalno-intelektualnej - sposobie wprowadzania w filozofię licealistów i studentów. Naucza się jej w porządku historycznym, skupiając się na chronologii oraz przedstawiając filozoficzne koncepcje jako teorie wyrafinowane intelektualnie i oderwane od świata zwykłych ludzi teorie. Teorie, które czasami wchodzą we wzajemne interakcje i bardzo w interakcje rzadko ze światem. Że można i należy inaczej pokazuje autor, przyglądając się trzem strategiom nauczania: historycznej, problemowo-życiowej oraz zagadnieniowo-historycznej. Główną część artykułu poświęca on właśnie opisowi tych strategii w oparciu o analizę najbardziej popularnych w Polsce podręczników do filozofii.

Słowa kluczowe: nauczanie filozofii, strategie nauczania, filozofia mądrościowa, odpowiedzialność filozofa

\section{Wstępne rozpoznania}

Do napisania tego tekstu skłoniły mnie dwa wydarzenia ze świata kulturalno-społecznego. Od dłuższego czasu jestem regularnym „oglądaczem” sztandarowego programu Hala odlotów produkowanego przez kanał TVP Kultura. Nadawany on jest w czwartki, między 20.00 a 21.00, czyli w porze największej oglądalności, a potem jeszcze kilkakrotnie w ciągu tygodnia jest powtarzany. Każde wydanie tego programu poświęcone jest jakiemuś ważnemu i w miarę aktualnemu, tematowi. Ostatnimi czasy omawiane były takie problemy jak na przykład: Emigracja, Jakość debaty publicznej, Oblicza wojny, Miłość w czasach ponowoczesnych, Problem tabu, Po co książki?, Tożsamość polska, Podróże, Inwigilacja ${ }^{1}$. Na te i tym podobne tematy, organizatorzy programu, Katarzyna Janowska i Max Cegielski, dyskutują z zaproszonymi gośćmi. Są to dziennikarze, aktorzy, socjologowie, psychologowie, naukowcy, pisarze, aktorzy, celebryci oraz specjaliści z zakresu omawianych właśnie tematów. Nie zdarzyło się natomiast, by wśród zaproszonych był filozof!

Podobny brak przedstawicieli filozofii uderzył mnie w czasie debaty zorganizowanej podczas Pomorskiego Kongresu Obywatelskiego w 2012 roku. Do dyskusji na temat

1 Spis tematów i nagrań wielu tych audycji można znaleźć pod adresem: http://vod.tvp.pl/audycje/kultura/ hala-odlotow. 
cenionych, przez mieszkańców Pomorza i przez współczesnych Polaków, wartości zaproszono profesora socjologii, profesora psychologii, profesora pedagogiki, pisarza, konsultanta aksjologicznego oraz licealistkę2. O filozofie, jak widać, zapomniano!

Czyżby rzeczywiście filozofia miała tak niewiele do powiedzenia o sprawach ważnych (i często niełatwych) dla świata i współczesnego człowieka?!

Myślę, że zaobserwowane sytuacje niewiary w to, że spojrzenie filozoficzne może coś istotnego i interesującego wnieść do ogólnokrajowych debat o ważnych problemach, nie jest zjawiskiem jednostkowym. Wykluczanie filozofii i filozofów ma szeroki zasięg.

Sytuacja ta inspiruje do zastanowienia się nad przyczynami takiego stanu rzeczy.

Myślę, że małoznaczące miejsce filozofii w prawie wszystkich wymiarach życia publicznego w Polsce wiąże się z charakterem głównego nurtu polskiej kultury oraz ze współczesnym system edukacji. W polskiej tradycji kulturowej od wieków pozycję bliską monopolistycznej w zakresie intelektualnej interpretacji rzeczywistości, ma dyskurs polityczny i spojrzenie dekretowane przez literaturę i poezję. W swej wypowiedzi nie ten wątek chcę jednak rozwijać...

Powodów eliminacji, ze społecznej debaty, filozoficznego spojrzenia szukałbym nie tylko $\mathrm{w}$ preferencjach intelektualnych redaktorów wpływowych mediów oraz środowisk opiniotwórczych, lecz również, a może nawet przede wszystkim, w postawach i działaniach samych filozofów. Mam tu głównie na myśli, realizowany przez polskie szkolnictwo średniego i wyższego szczebla, model kształcenia filozoficznego.

Interesuje mnie zatem sprawa edukacji. Nie mają racji ci, który mówią, że w polskim szkolnictwie filozofia jest nieobecna. W tym aspekcie ze szkolnictwem nie jest tak źle. Przecież, choć często w nie za dużym wymiarze, filozofia jest wykładana na prawie wszystkich kierunkach studiów. Od niedawna istnieje też możliwość nauczania jej, już na poziomie szkoły średniej! Co prawda, nie wszystkie szkoły z tego prawa korzystają, ale w tych najlepszych uważa się, że filozofia jest niezbędną częścią wykształcenia współczesnego Polaka. Dlatego jestem przekonany, że filozofia nie jest czymś nieznanym polskiemu inteligentowi!

Myślę jednak, że większość nauczających nie wykorzystuje danej im możliwości uczynienia z filozofii ważnej części polskiego życia intelektualnego, społecznego i kulturalnego. I uważam, że w znacznej części winna jest tu strategia nauczania filozofii. Kierując się fałszywym mniemaniem, iż możliwe jest jej nauczanie w sposób całkowicie zobiektywizowany, nauczyciele i wykładowcy przez lata wprowadzali młodych ludzi w filozofię, ucząc jej jako dziedziny wiedzy abstrahującej od życia zwykłych ludzi oraz wydarzeń niesionych przez kulturę, życie społeczne i postęp techniczny. W rezultacie filozofia jawiła się - podobnie jak wyższa matematyka czy fizyka teoretyczna - jako coś ważnego, ale zrozumiałego w swej istocie i przydatnego tylko wybitnym fachowcom. Aby pokazać łączność, a często i przydatność, filozofii z innymi obszarami wiedzy oraz ludzkiej aktywności, trzeba je (tj. te dziedziny) znać i rozumieć.

Warto zauważyć, że ukazywanie filozofii jako swoistej, sobie wystarczalnej, wiedzy jest też wygodne z punktu widzenia wielu z tych, którzy jej nauczają - można się tylko w jednym specjalizować, nie trzeba być interdyscyplinarnym. Co więcej, wielu uczących jest przekonanych (moim zdaniem błędnie), że znajomość wiedzy podstawowej, czyli

${ }^{2}$ Informacje o nim dostępne są pod adresem: http://www.gdansk.pl/galeria?c=1494. 
filozofii, daje dostęp do rozumienia wszystkiego. Taka postawa miała rację bytu w starożytności, kiedy ogólna ilość wiedzy nie była wielka i wszystko było z filo-sofia powiązane. Dziś, gdy ilość wiedzy jest ogromna, sama znajomość tradycji filozoficznej nie wystarczy! Dziś sporego wysiłku wymaga posiadanie orientacji chociażby w dwóch dziedzinach. Jak widać, prościej i wygodniej jest być „specjalistą” tylko od filozofii - i leży to w interesie wielu jej nauczających. Skutki wyboru łatwiejszej strategii nauczania w krótszej perspektywie czasowej nie są zauważalne, w dłuższej przyczyniają się do marginalizacji filozofii i spychana jej na „rynku idei” na zaściankowe pozycje.

Przyczyną takiego stanu rzeczy jest realizowana przez większość nauczycieli filozofii strategia nauczania. Nauczanie oczywiście nie jest zawieszone w próżni, lecz bazuje na programach i podręcznikach. Dlatego też zasadne wydaje się zbadanie tego, jakie strategie nauczania realizują funkcjonujące w naszym kraju podręczniki do filozofii.

\section{W poszukiwaniu strategii - niemoc dydaktyków filozofii}

W przeciągu dwóch i pół tysiącu lat istnienia filozofia „wytworzyła” olbrzymią ilość wiedzy. Składają się na nią twierdzenia, teorie, hipotezy, polemiki, dyskusje, a także życiorysy (zarówno życiowo-zawodowe, jak i intelektualne) samych filozofów. Trudno to wszystko ogarnąć. I dlatego, że ilość tych „produktów” jest ogromna, i dlatego, że w wielu miejscach tego „filozoficznego oceanu” trudno wyznaczyć granicę między filozofią a innymi naukami, tak humanistycznymi, jak i społecznymi, przyrodniczo-technicznymi oraz formalnymi. Dlatego potrzebna jest jakaś zasada, która, konsekwentnie realizowana, podpowiadałaby jak, w miarę sprawnie w tym wielkim obszarze należy się poruszać. Właśnie przez strategię chcę tutaj rozumieć pewną ideę albo, precyzyjniej rzecz ujmując, pewien pomysł na zasadę, czyli na algorytm, według którego badacz powinien starać się przedrzeć przez ten ocean filozoficznej wiedzy. W szczególności w tym tekście interesuje mnie to, jaką należy obrać strategię, by skutecznie i mądrze nauczać filozofii?

Odpowiedzieć na to pytanie jest niełatwo. Kłopot pojawia się już na początku drogi. Nie znajdziemy jej (tj. odpowiedzi) bowiem w miejscu, gdzie przede wszystkim powinna się znajdować, a mianowicie w książkach do dydaktyki filozofii.

Niewiele prac traktujących o dydaktyce filozofii opublikowano w Polsce do tej pory. W obiegu dostępne są tylko trzy ${ }^{3}$. Są to Zarys dydaktyki filozofii (Śleziński 20oo), relatywnie niedawno wydana książka zatytułowana Pokochać mądrość. Zarys dydaktyki filozofii i etyki (Bała i in. 2009) oraz praca napisana z myślą o rozpowszechnianiu nauczania filozofii wśród dzieci Filozofia w szkole (Lipman i in. 1996). Na przestrzeni ostatnich piętnastu lat ukazało się też kilka tomów zbiorowych będących efektem konferencji organizowanych przez uczelnie w Kielcach, Poznaniu, Częstochowie oraz w Warszawie. Z ich lektury nie wyłania się jednak jakaś spójna koncepcja dydaktyki filozofii i dlatego nie będę ich tutaj omawiał.

Spośród trzech wymienionych najbardziej znana jest książka autorstwa Krzysztofa Ślezińskiego, dlatego to jej postanowiłem się uważniej przyjrzeć. Krzysztof Śleziński, stając przed problemem, jak uczyć filozofii (by jej nauczyć), deklaruje, że jest świadom, iż podawanie samych faktów i związanych z nimi teorii, nie jest dobrym rozwiązaniem.

${ }^{3}$ Piszę w obiegu, a nie na rynku, bowiem prac tych nie ma już w księgarniach. Ich nakłady nie były wielkie i książki szybko się rozeszły. Jak na razie wznowień brak. 
Dostrzega potrzebę związania podawanych treści, rozumianych jako zapoznawanie się z głównymi nurtami i poglądami najważniejszych filozofów, ze sprawami ważnymi dla młodych ludzi i ważnymi dla epoki, w której żył aktualnie omawiany autor. Krzysztof Śleziński jest przekonany, że w nauczaniu filozofii nie chodzi o dobre pamięciowe opanowanie pewnej ilości (jak największej) dat, nazwisk, terminów, faktów, lecz o nauczanie myślenia nakierowanego na poznawanie prawdy, dobra i piękna. Zdaniem autora to twórcze, a nie odtwórcze, nastawienie winno polegać na pomaganiu młodym ludziom w zdobywaniu umiejętności dostrzegania w rzeczywistości problemów filozoficznych ${ }^{4}$ oraz umiejętności ich opisywania i rozwiązywania. Krzysztof Śleziński pisze na przykład: „Mimo istniejących licznych rozbieżności w podejściu do nauczania filozofii w różnych krajach demokracji zachodniej, elementem wspólnym stała się kwestia upodobnienia nauczania-uczenia się filozofii do procesu badawczego" (Śleziński 2000, s. 11). To związanie nauczanych treści filozoficznych z poznawaniem rzeczywistości i z filozofowaniem winno, zdaniem Krzysztofa Ślezińskiego, być osiągane poprzez:

- zintegrowanie procesu dydaktycznego z procesem wychowania;

- uczynienie tego współgrania przedmiotem analiz teoretycznych;

- uczynienie z filozofii także narzędzia do odnalezienia, przez młodych ludzi, swego miejsca w porządku cywilizacyjnym;

- pokazanie, że poznawanie idei filozoficznych może mieć znaczenie dla egzystencjalnych wyborów młodego (i nie tylko młodego) człowieka (Śleziński 200o, s. 11-12).

O tych powiązaniach między rzeczywistością społecznego, kulturalnego, cywilizacyjnego oraz codziennego życia pisze Krzysztof Śleziński we wstępie do swej pracy. Jest nawet świadom tego, iż nauczanie filozofii nie może być w pełni neutralne aksjologiczne (Śleziński 2000, s. 15-17). Jednak poszukiwanie w jego pracy bardziej precyzyjnych wskazówek czy też propozycji przeprowadzenia zajęć te szczytne cele realizujących jest bezowocne. Ponadto należy zauważyć, że układ i sposób prowadzenia wywodów w pracy Krzysztofa Ślezińskiego niewiele różni go od innych książek z zakresu dydaktyki. Podobnie mógłby być napisany podręcznik do dydaktyki psychologii, socjologii czy też fizyki. Autor nie wykorzystuje tej siły filozofii, która wiąże się z kontekstem jej powstania - z poszukiwaniem zrozumienia świata, w którym człowiekowi przyszło żyć! I siły związanej z kontekstem jej wykorzystywania - poczynione na obszarze filozofii rozstrzygnięcia mogą w bardzo istotny sposób ważyć na życiowych rozstrzygnięciach wybierającego! Autor podręcznika nie pokazuje, jak wykorzystać olbrzymi potencjał egzystencjalno-cywilizacyjny tkwiący w refleksji filozoficznej ${ }^{5}$. Ogranicza się do ukazania, jak odtwórczo zajmować się filozofią.

Trochę lepiej sprawa osadzenia nauczania filozofii w doświadczaniu świata wygląda w pracy Macieja Bały, Janiny Jeziorskiej i Sabiny Zalewskiej. Ale i tu nie znajdziemy rozważań na temat wyboru najwłaściwszej strategii nauczania filozofii.

4 Wśród rodzajów problemów, jakie ma na myśli, wymienia ontologiczno-metafizyczne, gnozeologiczne oraz etyczno-moralne. Pomija natomiast równie istotne problemy natury aksjologicznej, antropologicznej i estetycznej.

${ }_{5}$ O pewnych możliwościach pisałem w artykule pt. O sztuce nauczania filozofii (Dymarski 2001, s.39-43). 


\section{Trzy strategie}

Jaką obrać strategię, by skutecznie i mądrze nauczać filozofii?

Odpowiedź na to niełatwe pytanie postaram się wskazać w oparciu o analizę różnych strategii nauczania filozofii realizowanych przez dostępne na polskim rynku podręczniki. Do chwili obecnej ukazało się już ponad dwadzieścia prac stawiających sobie za cel nauczanie filozofii. Są wśród nich i dzieła oryginalne, napisane przez polskich autorów, są i tłumaczenia prac powstałych w innych krajach przynależnych do kręgu cywilizacji zachodniej.

Czasy, gdy na rynku dostępnych było tylko kilka podręczników, minęły. Od powojnia do końca lat 6o. w obiegu był właściwie tylko jeden - trzytomowa Historia filozofii Władysława Tatarkiewicza. W końcu lat 6o. ukazały się prace Zdzisława Cackowskiego Główne zagadnienia i kierunki filozofii oraz Adama Sikory Spotkania z filozofia. A wydawnictwo PIW wydało, przetłumaczoną przez Jana Szewczyka, Historię filozofii Ernsta von Astera. W latach 7o. doszedł jeszcze podręcznik autorstwa Leszka Kasprzyka i Adama Węgrzeckiego. Ich Wprowadzenie do filozofii charakteryzuje się ciekawym pomysłem na prezentowanie treści filozoficznych. Składał się on z wprowadzenia i czterech obszerniejszych części. We wprowadzeniu autorzy omawiali pojęcie filozofii i jej działy, w części pierwszej zagadnienia ontologiczne, $w$ drugiej epistemologiczne, a w trzeciej społeczne i antropologiczne. Część czwarta zawierała omówienie dwudziestowiecznych (czyli powstałych po marksizmie) kierunków filozoficznych. Każda z wymienionych części zaopatrzona została w podrozdział zawierający ocenę omawianych zagadnień z punktu widzenia filozofii marksistowskiej. I najprawdopodobniej to te fragmenty książki były daniną, jaką musieli zapłacić ówczesnej władzy autorzy za wydanie tego niemarksistowskiego podręcznika ${ }^{6}$. W tamtych czasach książka do filozofii, w której marksizm nie byłby najważniejszą i najdojrzalszą doktryną, nie miała wielkich szans na ukazanie się̨. Dodać należy, iż w okresie komunizmu jako obowiązujący podręcznik forsowana była przez ówczesne władze inna jeszcze książka - praca zbiorowa zatytułowana Filozofia marksistowska (Grudzień i in. 1970). Wymieniam ją gwoli prawdy historycznej, ale nie będę się nią zajmował. Była to bowiem bardzo ideologicznie ustawiona praca i w żaden sposób nie powinna być przewodnikiem dla współczesnych krzewicieli wiedzy filozoficznej.

Przeprowadzone analizy wydanych w Polsce książek do filozofii pozwalają mi stwierdzić, że możemy mówić o trzech strategiach nauczania. Są to:

1) strategia historyczna,

2) strategia problemowo-życiowa,

3) strategia zagadnieniowo-historyczna.

" Praca ukazała się po raz pierwszy w 1974 roku w sporym nakładzie i miała kilka wznowień. W 2002 roku Adam Węgrzecki samodzielnie wydał tę pracę w przeredagowanej formie i bez „odmarksistowskich” komentarzy. I aby odróżnić się od poprzednich edycji zatytułował ją Zarys filozofii (Węgrzecki 2002).

7 Historia filozofii Władysława Tatarkiewicza jest wyjątkiem od tej zasady, ale i jej publikacja spotkała się z dużymi kłopotami. O trudnościach związanych z publikacją trzeciego, najbardziej współczesnego, tomu Historii filozofii pisze między innymi Józef Tischner w wydanej w drugim obiegu pracy o przewrotnym tytule Polski kształt dialogu (Tischner 1980, s.37-41). 
Podręcznik, by był podręcznikiem właśnie, nie może być katalogiem faktów i komentarzy do nich. Zawsze powinien proponować jakiś sposób porządkowania i przedstawiania filozoficznych treści. W związku z tym, że strategie nauczania będę omawiać w oparciu o funkcjonujące na rynku podręczniki, muszę najpierw powiedzieć, czym jest dobry podręcznik. Otóż powinien on charakteryzować się następującymi cechami:

- zaciekawić, czyli nie nużyć;

- nie przytłaczać ogromem wiedzy;

- sensownie, konsekwentnie (logicznie) prowadzić wywody;

- umiejętnie wiązać teorię z opowieścią o świecie i o człowieku ten świat zagospodarowującym;

- być reprezentatywny, to znaczy prezentować i omawiać te zagadnienia, które w tradycji są uznane za najważniejsze, a pomijać te, które są mało ważne;

- nie stronić od ilustracji, wykresów i zdjęć, gdy mogą one być pomocne w uchwyceniu jakiegoś problemu.

Pierwszą z wymienionych strategię - historyczną - realizuje najbardziej znany polski podręcznik do filozofii, a mianowicie Historia filozofii Władysława Tatarkiewicza. Możemy ją odnaleźć również w innych książkach, takich jak na przykład: Krótka historia filozofii Roberta C. Solomona i Kathleen M. Higgins (1997) oraz powieści-podręczniku Świat Zofii Josteina Gaardera (1995). Taką strategię realizuje również trzytomowy wybór tekstów źródłowych z komentarzami, przygotowany przez Barbarę Markiewicz (1999a, 1999b, 1999c) oraz podręcznik dla szkół ponadgimnazjalnych Kamyk filozoficzny (Lasocińska 2007; Mazur 2010). Taki pomysł na przybliżanie filozofii prezentuje także - ceniona przez mnie ze względu na dużą ilość rysunków i wykresów ilustrujących omawiane teorie - praca trojga niemieckich autorów: Petera Kunzmanna, Franza-Petera Burkarda i Franza Widmanna Atlas filozofii (1999). Wszystkich prac realizujących tę strategię nie ma możliwości i potrzeby wymieniać oraz omawiać. W tym artykule skupię się na książce Władysława Tatarkiewicza.

Historia filozofii to niezwykle ważna praca. Zaczęła ona powstawać, na zamówienie Ossolineum, jeszcze w latach 30. XX wieku. Przez cały czas PRL-u, a nawet nieco dłużej, był to jedyny podręcznik do filozofii godny uwagi. Praca Tatarkiewicza ustaliła wyobrażenia kilku pokoleń polskich inteligentów na temat tego, czym jest filozofia i kto to jest znawca filozofii ${ }^{8}$. Konsekwencje tego obserwujemy do dziś - dla średniego i starszego pokolenia polskiej inteligencji, znajomość filozofii równoznaczna jest $\mathrm{z} \mathrm{w}$ miarę biegłym opanowaniem treści pomieszczonych w Historii filozofii Władysława Tatarkiewicza!

W filozofii bardziej pociągało Władysława Tatarkiewicza stwierdzanie faktów ${ }^{9}$ niż ich wyjaśnianie (Tatarkiewicz 1998, s. 194). Filozof chciał bowiem, jak sam deklaruje (Tatarkiewicz 1980, s. 10), uczynić swoją pracę maksymalnie przejrzystą i łatwą w lekturze ${ }^{10}$.

8 Od czasu wydania w 1931 roku pierwszego tomu praca miała ponad dwadzieścia wydań!

9 Jednoznaczne rozstrzygnięcie, co w filozofii i w ogóle w naukach humanistycznych i społecznych jest faktem, jest trudne.. Przykładem tego może być chociażby krytyka rozstrzygnięć Emila Durkheima w kwestii faktów społecznych. Tu jednak należy wnosić, że Tatarkiewiczowi chodziło o elementarnie proste informacje biograficzne i najprostsze elementy teorii, tzn. jak najmniej jeszcze zinterpretowane.

10 Takie nastawienie metodologiczne w pracach Władysława Tatarkiewicza dostrzega też badacz jego twórczości Ryszard Wiśniewski (Wiśniewski 2011-2013, s.473-485). 
Dlatego przed wydaniem Historia filozofii była poddana kilku starannym i gruntownym redakcjom. W efekcie rzeczywiście czyta się ją relatywnie łatwo.

Ale oprócz zalet podręcznik ma również sporo wad. Przede wszystkim zauważyć należy, iż Historia filozofii jest bardziej zbiorem opowieści o filozofach niż historią pytań i problemów filozoficznych. Sposób organizacji treści sprawia, że czytelnikowi trudno jest poznać naturę najważniejszych filozoficznych zagadnień i śledzić dzieje ich rozwoju. Jej strukturę z historycznym układem treści można odtworzyć w poniższy sposób:

Struktura Historii filozofii Władysława Tatarkiewicza

\section{Tom 1}

\section{Filozofia starożytna}

a. Pierwszy okres filozofii starożytnej

b. Drugi okres filozofii starożytnej

c. Trzeci okres filozofii starożytnej

d. Końcowy okres filozofii starożytnej

e. Filozofia chrześcijańska

Filozofia średniowieczna

a. Pierwszy okres filozofii średniowiecznej

b. Drugi okres filozofii średniowiecznej

c. Końcowy okres filozofii średniowiecznej

\section{Tom 2}

Filozofia nowożytna

a. Pierwszy okres filozofii nowożytnej

b. Drugi okres filozofii nowożytnej

c. Trzeci okres filozofii nowożytnej

d. Czwarty okres filozofii nowożytnej

\section{Tom 3}

Filozofia XIX wieku

a. Faza pierwsza

b. Faza druga

c. Faza trzecia

Filozofa XX wieku

a. Faza pierwsza

b. Faza druga

c. Faza trzecia

źródło: opracowanie własne

W Historii filozofii Władysława Tatarkiewicza okresy historii Europy są podstawowym „kośćcem” organizacyjnym. W odwołaniu do nich opowiadane są dzieje filozofii. Każda faza historii ma kilku najważniejszych filozofów, których sylwetki i poglądy Tatarkiewicz charakteryzuje. Widać, że tu strategia nauczania filozofii ma charakter historyczny.

Podstawowymi elementami, można powiedzieć - „cegłami”, konstrukcji filozofii są w książce Władysława Tatarkiewicza poszczególni filozofowie. W ich (tj. tych filozofów) charakterystyce ważne są poglądy, terminy, jakie skonstruowali i jakimi najczęściej się posługiwali, napisane przez nich książki oraz lata, w jakich żyli. Struktury poszczególnych podrozdziałów, w których ma miejsce charakterystyka sylwetek i dorobku naukowego ważnych filozofów, są do siebie zbliżone i mają następującą postać: 
Struktura podrozdziałów w Historii filozofii Władysława Tatarkiewicza

$$
\begin{aligned}
& \text { - poprzednicy, } \\
& \text { - życiorys, } \\
& \text { - pisma, } \\
& \text { - poglądy, } \\
& \text { - znaczenie, } \\
& \text { - wpływ/uczniowie, } \\
& \text { - opozycja. }
\end{aligned}
$$

źródło: opracowanie własne

Chronologii podporządkowana zostaje kolejność prezentacji ważnych myślicieli. To pojawiające się po sobie nazwiska - a nie zagadnienia filozoficzne jako próby naświetlenia, zrozumienia i rozwiązania jakichś wyzwań danego miejsca i czasu - stanowią podstawowe elementy, z których skonstruowany został wielki gmach filozofii w pracy Władysława Tatarkiewicza.

Rezultatem posłużenia się taką, prostą i gwarantującą wyrazistość tzw. faktów, zasadą jest pominięcie otoczenia, tzn. kontekstu intelektualnego, cywilizacyjno-technicznego, społecznego i kulturowego, z jakiego wyrosła taka właśnie, a nie inna koncepcja filozoficzna. Autor z pewnością ma tę wiedzę, bo czytał i dzieła poszczególnych filozofów, i liczne szczegółowe opracowania, ale tą wiedzą z czytelnikiem się nie dzieli. Pisze on tak, jakby powstawanie i rozwój idei filozoficznych odbywały się w jakiejś odseparowanej, od „czasowiącej się” rzeczywistości intelektualno-społeczno-kulturalno-cywilizacyjno-egzystencjalnej, przestrzeni!

Podobne uwagi do charakteru pomieszczonych w Historia filozofii treści wyraził ostatnio Piotr Nowak. Uważa on, że ta książka Tatarkiewicza jest wypłukana z życia, że można ją od biedy przyswoić pod kątem wymogów egzaminacyjnych, ale nie można nią oddychać (Nowak 2014, s. 163).

Władysław Tatarkiewicz, uczeń twórcy szkoły lwowsko-warszawskiej Kazimierza Twardowskiego, był pod silnym wpływem teorii teoriopoznawczych wzorowanych na naukach ścisłych. Najprawdopodobniej uważał, że „fakt filozoficzne” mają podobny status teoriopoznawczy, jak fakty fizyczne, chemiczne czy też biologiczne, i dlatego należy je przyjmować jako obowiązujące od chwili ogłoszenia. Tymczasem w naukach humanistycznych, o czym pisali na przykład Martin Heidegger i Hans-Georg Gadamer, nie sposób oddzielić faktów od ich rozumienia. W innych relacjach względem siebie są tu konteksty odkrycia, wyjaśnienia i akceptacji ${ }^{11}$.

Strategia problemowo-życiowa najpełniej, moim zdaniem, jest realizowana przez trzytomikową pracę Leszka Kołakowskiego zatytułowaną Mini wykłady o maxi sprawach (1997, 1999, 2000). Jest ona zapisem krótkich, kilkunastominutowych wykładów, które filozof z Oxfordu wygłaszał dla widzów Telewizji Polskiej w końcu lat 9o. W wykładach Kołakowski mówi o sprawach interesujących, acz trudnych niekiedy...

11 O tych aspektach odkrywania, formułowania i wyjaśniania teorii na gruncie nauk ścisłych pisał przed laty Józef Życiński (Życiński 1985, s. 216-132). 
Filozofia chciałaby zanalizować i wytłumaczyć całość rzeczywistości, ale to jest niewykonalne ${ }^{12}$. Dlatego też Leszek Kołakowski szuka takich punktów widzenia i takich kluczy, które otwierają maksymalnie dużą liczbę drzwi do poznania rzeczywistości. W tradycji filozoficznej kluczami są takie kategorie jak: byt, dobro, zło, człowiek, Bóg, egzystencja, świadomość, rozum, prawda, kultura, nauka - dość szczegółowe ich omówienie można znaleźć na przykład w pracy Ekkeharda Martensa i Herberta Schnädelbacha Filozofia. Podstawowe pytania (1995). Leszek Kołakowski, chcąc uczynić filozofię bardziej zrozumiałą człowiekowi współczesnemu, zrezygnował z tych, obciążonych już balastem filozoficznego żargonu, kategorii i do filozoficznego rozpracowania obrał sobie pojęcia i sprawy, które wydają się leżeć bliżej głównych nurtów życia społeczeństw tworzących cywilizację Zachodu. Co więcej, wydają się one być węzłami ważnych dyskursów toczących się we współczesnym świecie.

Omawiane problemy są zatem natury egzystencjalnej i kulturowej. Wśród analizowanych są sprawy bardzo doniosłe, jak na przykład, sprawa odpowiedzialności, posiadania samego siebie i wolności, oraz sprawy bardziej codzienne, acz ważne, takie jak na przykład sprawa młodości, nicnierobienia czy też bicia rekordów. Leszek Kołakowski problemy te stara się opisać i wyjaśnić, korzystając ze znajomości bardzo wielu dzieł z obszaru filozofii i kultury, a także w odwołaniu do swoich obserwacji życia Europejczyków żyjących (jeszcze całkiem niedawno) po obu stronach żelaznej kurtyny. Omawiane problemy są tytułami rozdziałów trylogii. Ich pełny zestaw zamieszczam poniżej.

Mini wykłady o maxi sprawach - spis problemów

\begin{tabular}{|c|c|c|}
\hline $\begin{array}{l}\text { Mini wykłady o maxi spra- } \\
\text { wach, tom pierwszy } \\
\text { 1. O władzy } \\
\text { 2. O sławie } \\
\text { 3. O równości } \\
\text { 4. O kłamstwie } \\
\text { 5. O tolerancji } \\
\text { 6. O podróżach } \\
\text { 7. O cnocie } \\
\text { 8. O odpowiedzialności } \\
\text { zbiorowej } \\
\text { 9. O kole fortuny } \\
\text { 10. O wielkiej zdradzie } \\
\text { 11. O przemocy } \\
\text { 12. O wolności } \\
\text { 13. O nudzie } \\
\text { 14. Matematyk i mistyk }\end{array}$ & $\begin{array}{l}\text { Mini wykłady o maxi sprawach, } \\
\text { tom drugi } \\
\text { 1. O Bogu } \\
\text { 2. O szacunku dla natury } \\
\text { 3. O zabobonach } \\
\text { 4. O śmiechu } \\
\text { 5. O świętych } \\
\text { 6. O terroryzmie } \\
\text { 7. W sprawie seksu } \\
\text { 8. O młodości } \\
\text { 9. O nicnierobieniu } \\
\text { 10. O sumieniu } \\
\text { 11. O tym, co dobre } \\
\text { i co prawdziwe } \\
\text { 12. O karze głównej } \\
\text { 13. O stereotypach narodowych } \\
\text { 14. Udręczenie }\end{array}$ & $\begin{array}{l}\text { Mini wykłady o maxi } \\
\text { sprawach, tom trzeci } \\
\text { 1. O długach } \\
\text { 2. O wybaczaniu } \\
\text { 3. O rekordach } \\
\text { 4. O posiadaniu samego } \\
\quad \text { siebie } \\
\text { 5. O przeszłości } \\
\text { i o przyszłości } \\
\text { 6. O zawiści } \\
\text { 7. O sprawiedliwości } \\
\text { 8. O pogrzebach } \\
\text { 9. O maskach } \\
\text { 10. O wrogu i przyjacielu } \\
\text { 11. Demokracja jest prze- } \\
\text { ciwna naturze } \\
\text { 12. Moje wróżby w sprawie } \\
\text { przyszłości religii i filozofii }\end{array}$ \\
\hline
\end{tabular}

źródło: opracowanie własne

12 Pisze na przykład Leszek Kołakowski: „co to jest całość, tego rozum nie wie i wiedzieć nie może” (Kołakowski 2009, s. 207). 
Strategia problemowo-życiowa realizowana w pracy Leszka Kołakowskiego, nie porządkuje poglądów i koncepcji filozoficznych - jak czyni to klasyczny wykład z historii zagadnień filozoficznych albo z historii filozofów - według klucza czasowego. Omawiając przedstawione powyżej kategorie, filozof z Oxfordu stara się w pierwszej kolejności je opisać, następnie ustalić miejsce w przestrzeni kultury zachodniej, a na końcu filozoficznie dodefiniować. W swoich analizach nie stroni od wskazania ich związków z historią, życiem indywidualnym i zbiorowym, literaturą, religią, prawem, kulturą... Dodać należy, iż tak syntetycznie i tak wieloaspektowo pisać o różnorodnych zagadnieniach może tylko wytrawny filozof, a takim niewątpliwie był Leszek Kołakowski.

Realizowana w Mini wykładach o maxi sprawach strategia problemowo-życiowa, uprzystępnia filozofię, pokazuje, że może ona być czymś bliskim i ważnym w życiu każdego człowieka. A nie tylko zawodowego filozofa, dodajmy. Kołakowski przedstawia filozofię nie jako elitarną i trudną naukę, ale jako wiedzę i umiejętności pomagające nazwać i zrozumieć sprawy ważne. Książka ta nie jest jednak klasycznym podręcznikiem do filozofii, nie spełnia bowiem niektórych wymagań stawianych podręcznikom. Jest jedynie zachętą i wprowadzeniem do filozofii.

O wartości tego typu strategii, którą posłużył się Kołakowski pisząc Mini wykłady o maxi sprawach i oczywiście o jakości pracy samego filozofa, świadczy to, że trylogia ta doczekała się kilku wydań, a łączny nakład osiągnął kilkadziesiąt tysięcy egzemplarzy ${ }^{13}$.

Podręcznikiem w pełnym tego słowa znaczeniu, realizującym strategię problemowo-życiową, jest praca Jacka Wojtysiaka ${ }^{14}$. To, że autor chce wprowadzać w filozofię od strony życia, sygnalizuje od razu na początku poprzez tytuł swej książki: Filozofia $i \dot{z} y c i e$ (Wojtysiak, 2007). Ta deklaracja nie znaczy, że bierze on na warsztat tematy wprost z życia i przygląda się im „filozoficznym okiem”. Każdy z piętnastu rozdziałów książki dotyczy jakiegoś istotnego problemu. Nie są to jednak zagadnienia tak bardzo blisko dotykające życia, jak to było w pracy Leszka Kołakowskiego. Są one już nieco obrobionymi kategoriami opisującymi rzeczywistość. Zaryzykuję twierdzenie, że są pojęciami, do których odnieść się musi każdy światopogląd. To ludzkie zanurzenie w świecie decyduje o tym, że takie a nie inne kategorie chce w swoim podręczniku omawiać Jacek Wojtysiak.

Co więcej, sposoby odnoszenia się człowieka do otaczającej go rzeczywistości uczynił Jacek Wojtysiak zasadą porządkującą zbiór tych wybranych kategorii. Twierdzi on za Arystotelesem, że człowiek świat poznaje, w świecie działa i w świecie coś wytwarza. Te trzy sfery aktywności spaja, zdaniem Wojtysiaka, odniesienie do sacrum. Po uwzględnieniu zaprezentowanego kontekstu struktura podręcznika wygląda następująco:

${ }^{13}$ Sukces tej książki sprawił, że na początku XXI wieku filozof wygłosił i wydał nowe trzy serie wykładów. W konstrukcji nowej pracy wykorzystał jednak Kołakowski strategię historyczną. Nowej książce nadał tytuł O co pytają nas wielcy filozofowie? (Kołakowski 2004, 2005, 2006) i poświęcił ją pokazaniu najważniejszych pytań i problemów, wokół których koncentrowała się myśl najwybitniejszych filozofów.

14 Książka ta jest rozwinięciem problematyki zawartej we wcześniejszej pracy Jacka Wojtysiaka zatytułowanej Filozofia. Pochwała ciekawości (2003). 
Struktura podręcznika Filozofia i życie Jacka Wojtysiaka

\begin{tabular}{|l|l|}
\hline 1. Poznanie & 3. Wytwarzanie \\
a. wiedza & a. dzieło sztuki \\
b. zdrowy rozsadek & b. sztuka a filozofia \\
$\begin{array}{l}\text { c. między kosmologią a ontologią } \\
\text { d. światopogląd }\end{array}$ & c. pieniądz a praca \\
\hline 2. Działanie & 4. Sacrum \\
a. człowiek & a. Bóg \\
b. moralność & b. religia \\
c. szczęście & c. zło \\
d. społeczeństwo & d. śmierć \\
\hline
\end{tabular}

źródło: opracowanie własne

Wydaje się, że przedstawione powyżej zaszeregowanie kategorii do poszczególnych sfer nie we wszystkich przypadkach jest poprawne. Zresztą ten podział na cztery części główne związane z dystynkcjami zaproponowanymi przez Arystotelesa nie ma wpływu na treści pomieszczone $\mathrm{w}$ poszczególnych rozdziałach książki. Ważne natomiast jest to, że autor poprzez kategorie dość blisko związane z życiem ludzkim, chce wprowadzać w filozofię. To podejście „od strony życia” ma wpływ na strukturą każdego z piętnastu rozdziałów książki. Przedstawia się ona następująco:

Struktura rozdziałów w podręczniku Filozofia $i \dot{z} y c i e$

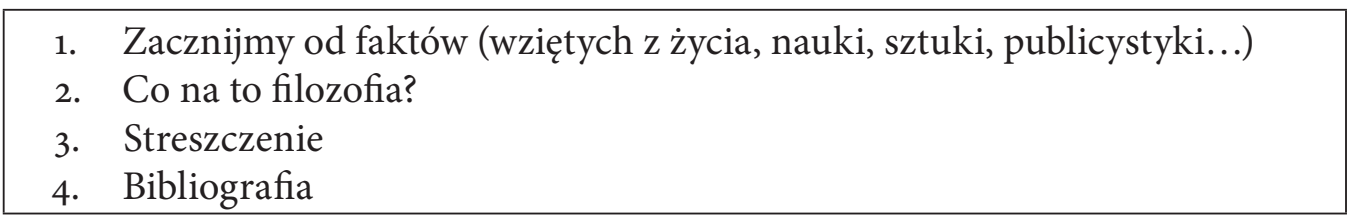

źródło: opracowanie własne

Na początku każdego rozdziału znajduje się omówienie tytułowego pojęcia widzianego oczami zwykłego człowieka. Bazuje ono albo na codzienno-problemowym doświadczeniu samego autora i jego przyjaciół albo odwołuje się do treści znajdywanych w prasie codziennej. W drugiej części, najobszerniejszej, autor opisuje omawiany problem na sposób filozoficzny. To znaczy, próbując go wyjaśnić, posiłkuje się streszczeniami bądź krótkimi cytatami z dzieł filozoficznych. Czasami sięga też po wyjaśnienia do obszaru literatury, religii i publicystyki wysokiego lotu - „by nie oddalić się od życia” (Wojtysiak 2007, s. 11), jak dodaje. Te filozoficzne wyjaśnienia mają charakter analityczno-problemowy i nie są powiązane żadną czasowo-historyczną narracją. Są wyjaśnieniem, które bazuje na odwołaniu się do eksperymentu i analizy, tak jak robi to, bliska Jackowi Wojtysiakowi, metoda analityczna. Autor nie rości sobie pretensji do jednoznacznego wyjaśniania problemu. Czyni tak i dlatego, że trudno w filozofii o bezdyskusyjne rozstrzygnięcia, i dlatego by zainspirować czytelników do dyskusji (z autorem i między sobą) oraz do podjęcia próby wypracowania własnego stanowiska. W Streszczeniu, w kilkunastu zdaniach, Wojtysiak 
omawia problem i prezentuje wnioski. Na końcu każdego rozdziału podaje bibliografię dotyczącą rozpatrywanego zagadnienia, głównie polskojęzyczną. Literatura ta ma podpowiedzieć tym, których omawiany problem zainteresował, gdzie mogą znaleźć wsparcie dla swych, właśnie rozbudzonych, filozoficznych zainteresowań.

Strategia trzecia, zagadnieniowo-historyczna, stara się pogodzić zalety obu poprzednich. Mocną stroną strategii historycznej (jeśli jest dobrze przeprowadzona) jest to, że nie ignoruje dziejowego podłoża ważnych dla filozofii problemów. Takie podejście pozwala dojrzeć, jaką drogę rozpoznawania zagadnienia już pokonano, jakie rozpoznania okazały się prawdziwe, a gdzie zbłądzono. Strategia problemowo-życiowa z kolei podkreśla, że wyzwania niesione przez życie mogą być także ważne dla filozofii oraz że filozofia może być pomocna człowiekowi, który pragnie zrozumieć świat i otaczających go ludzi ${ }^{15}$.

Strategia zagadnieniowo-historyczna przyjmuje, że ważne sprawy człowieka są również ważnymi sprawami, można nawet powiedzieć że intelektualnymi wyzwaniami, dla filozofii. I tak metafizyka jest próbą rozpoznania fundamentów rzeczywistości, czyli miejsca, gdzie żyje człowiek, epistemologia stara się rozpoznać, jak poznajemy i jakie są ludzkie ograniczenia w tym zakresie, etyka jest szukaniem odpowiedzi na pytanie o zasady mądrego życia. I sam człowiek jest tu wyzwaniem dla siebie, antropologia filozoficzna stara się bowiem zgłębić sprawę człowieka i poszukiwać odpowiedzi na pytanie o istotę człowieczeństwa, aksjologia jest tu rozumiana jako usiłowanie rozpoznania, co i dlaczego ma wartość, a teologia naturalna, ujmowana czasami (zasadnie, moim zdaniem) w szerszych ramach filozofii religii, jako nauka poszukująca odpowiedzi o istnienie i naturę Boga, jako gwaranta sensowności ziemskich spraw i mocy dobra.

$\mathrm{W}$ tej strategii każde $\mathrm{z}$ tych zagadnień dotyczy innego aspektu rozpoznawania przez człowieka rzeczywistości. Te rozpoznania mają swoją historię, to znaczy dzieje rozciągniętej w czasie drogi formowania i pogłębiania wiedzy o danym zagadnieniu oraz dzieje popełnianych na tej drodze błędów. Takie podejście nie ignoruje zatem historii dochodzenia do wiedzy, jaką obecnie posiadamy. A jednocześnie stanowi odejście od klasycznego wykładu historii filozofii, gdzie wymóg chronologii czasowej sprawia, że obok siebie albo zaraz po sobie umieszcza się różne, niemające ze sobą wiele wspólnego koncepcje i poglądy. W rezultacie czytelnik nie ma spójnego obrazu rozwoju jakiegoś zagadnienia lub działu filozofii.

Strategię zagadnieniowo-historyczną można już odnaleźć w książce Kazimierza Ajdukiewicza (1949) oraz wydanej w końcówce lat 8o. pracy austriackiego filozofa Arno Anzenbachera (1987). Ale najpełniej, co nie znaczy, że w sposób doskonały, tę strategię realizuje książka Jana Galarowicza Na ścieżkach prawdy (1991).

Autor uważa, że filozofia jest wiedzą mądrościową i pomaga poszukiwać odpowiedzi na fundamentalne dla każdego człowieka pytania. Co więcej, zauważa, że są one zbieżne z podstawowymi zagadnieniami-działami europejskiej filozofii. Sam Jan Galarowicz pisze o tym w następujący sposób: „Ponieważ filozofowanie polega przede wszystkim na odwadze stawiania doniosłych pytań, moja podstawowa troska jest skierowana na to, by sprowokować cię (czyli czytelnika książki - Z.D.) do postawienia tych pytań

15 W tym dążeniu nawiązuje do korzeni filozofii. Wszak powstała ona jako efekt wysiłku intelektualnego wybitnych Greków chcących wyjaśnić, czym jest otaczająca rzeczywistość i znaleźć radę, jak mądrze i dobrze, czyli szczęśliwie, przejść przez życie. 
i uświadomienia sobie sensu filozoficznych zagadnień. W tym celu w punkcie wyjścia rozważań zwraca szczególną uwagę na opis sytuacji i doświadczeń egzystencjalnych, z których owe pytania i zachowania wyrastają" (Galarowicz 1991, s. 20). Filozofia zaczyna się bowiem od odkrycia sytuacji problemowej i od pytania!

Jan Galarowicz, postępując za dziejącymi się w czasie poszukiwaniami, szuka odpowiedzi na pytania o rzeczywistość, o poznanie, o dobro, o człowieka i o Boga. A to są tematy głównych działów filozofii - metafizyki, epistemologii, etyki i aksjologii, antropologii filozoficznej i teologii naturalnej. Ta konstatacja porządkuje tematykę i zawartość poszczególnych rozdziałów jego książki. Bardziej szczegółowy jej plan zamieszczam poniżej.

Struktura książki Na ścieżkach prawdy Jana Galarowicza

\section{Co to jest filozofia?}

a. Potoczne pojmowanie filozofii.

b. Pochodzenie nazwy filozofii.

c. Z dziejów pojęcia filozofii/

d. Współczesne metody i style uprawiania filozofii.

e. Dominujące prądy we współczesnej filozofii polskiej.

f. Filozofia a inne dziedziny kultury.

g. Filozofia - myślenie istotne.

h. Jedność myślenia a wielość dyscyplin filozoficznych.

\section{Poznanie}

a. Elementy filozofii języka, logiki i filozofii nauki.

b. Prawda nas wyzwoli.

c. Spór o źródła poznania.

d. Granice poznania.

e. Poznaj samego siebie.

f. Zrozumieć drugiego człowieka.

\section{Rzeczywistość}

a. Fundamentalne pytania ontologiczno-metafizyczne. b. Wielkie systemy ontologiczno-metafizyczne.

c. Współczesna polska myśl ontologiczna i metafizyczna.

d. Wybrane problemy ontologiczno-metafizyczne.

\section{Bóg}

a. Idea Boga w filozofii Zachodu.

b. Drogi dowodzenia istnienia Boga.

c. Krytyka religii.

d. Bóg we współczesnej filozofii polskiej.

e. Od filozofii do wiary.

\section{Człowiek}

a. Wielkie systemy antropologiczne.

b. Współczesna polska myśl antropologiczna.

c. Wybrane problemy antropologiczne.

\section{Zakorzenić się w dobru}

a. Fundamentalne pytania filozofii wartości.

b. Kierunki i szkoły w etyce.

źródło: opracowanie własne

Przedstawiony powyżej zarys struktury książki jest w rzeczywistości jeszcze bardziej złożony. Na każdy podrozdział składają się bowiem mniejsze podrozdziały, w ramach 
których autor przedstawia, jak dany problem na przestrzeni dziejów starano się rozjaśnićc ${ }^{16}$. I tu pojawiają się nazwiska wielkich filozofów, ale jedynie w charakterze nazw wskazujących określone propozycje wyjaśnienia zagadnienia. Niestety w ujęciu Jana Galarowicza zagadnienia filozoficzne rozwijają się głównie siłą własnej logiki. To znaczy, że autor nie dostrzega związków filozofii z kulturą i polityką realizowaną w danej epoce. By wyjaśnić filozoficzne zagadnienia odwołuje się najczęściej do opisów doświadczeń egzystencjalnych i społecznych współczesności, a nie epoki, w której omawiane propozycje rozwiązań powstawały! Czasami takie postępowanie jest wystarczające, ale czasami nie. Niejednokrotnie lepiej by było, by autor opisał badany problem w kontekście rzeczywistości epoki, w którym prezentowane zagadnienie się zrodziło. Na przykład można byłoby zakreślić (oczywiście skrótowo) rzeczywistość siedemnastowiecznej nauki i na tym tle przedstawić propozycję poszukiwania pewności, jaką podał René Descartes. Albo opis Tomaszowej propozycji rozdzielenia filozofii od teologii można byłoby poprzedzić (też skrótowym) przedstawieniem sytuacji filozofii w średniowieczu. I podobnie postąpić na przykład z zagadnieniem podświadomości u Freuda i ateizmu u Nietzschego...

Omawiając różne propozycje rozwiązania jakiegoś problemu, Jan Galarowicz nie opowiada się za żadną ze stron. Nie uważa jednak, że filozofia jest zbiorem jednakowo ważnych koncepcji. Czasami, w dyskretny sposób, sam ujawnia swoje stanowisko. Czyni tak, nie po to by narzucić swoje przekonania, ale by pokazać, że sam też poszukuje odpowiedzi i w ten sposób zachęcić do wejścia w spór i rozpoczęcia dyskusji - jak jest naprawdę i dlaczego tak się sądzi. Filozofia to nie tylko wiedza o możliwych odpowiedziach na ważne pytania. To proces wglądu w nowe perspektywy i głębszego rozumienia rzeczywistości. Zamierzeniem Jana Galarowicza jest, by najpierw studenci i uczniowie zrozumieli, jak i dlaczego tak odpowiadali inni, a następnie by samodzielnie zaczęli poszukiwać najwłaściwszych rozwiązań prezentowanych dylematów ${ }^{17}$.

Uporządkować wiedzę i przemyśleć niektóre problemy mają pomóc zamieszczone na końcu rozdziałów streszczenia omawianych zagadnień, zestawy pytań oraz bibliografia podzielona na trzy części: teksty łatwiejsze, teksty trudniejsze oraz teksty źródłowe. Oprócz tego należy pochwalić autora za dużą ilość umieszczonych w tekście rysunków i wykresów będących graficznymi reprezentantami omawianych w poszczególnych rozdziałach koncepcji. Wydaje się, że niejednokrotnie graficzna prezentacja zagadnienia jest bardziej rozjaśniająca niż długi słowny wywód.

\section{Zamiast zakończenia}

By filozofią się zajmować, nie trzeba być posiadaczem uniwersyteckiego dyplomu zaświadczającego o ukończeniu studiów o takim profilu. Filozofami są ci wszyscy, którzy poszukują mądrości, czyli ci, którzy chcą zrozumieć. Filozofia nie jest tylko wiedzą o „faktach filozoficznych”. Jest poszukiwaniem mądrości!

16 Jan Galarowicz realizowaną przez siebie strategię określa jako łączącą podejście „problemowo-systematyczne z historycznym" (Galarowicz 1991, s.19).

17 „W filozofii nie chodzi bowiem tylko o to, by wiedzieć, jak inni rozstrzygają problemy, ale o to, by samemu stawiać problemy i szukać odpowiedzialnych rozstrzygnięć” (Tischner 1981, s. 3). 
Oczywiście można poszukiwać mądrości, wskakując od razu na głębię - w największy gąszcz filozoficznych dyskusji - czyli koncentrować się na poznawaniu poglądów najważniejszych filozofów i sporów, jakie ze sobą toczyli. Śledzić ich dyskusje prowadzone na wysokim stopniu abstrakcji, z dala od kontaktu z materią życia. Miłośnicy tego sposobu uprawiania filozofii podobni są do tych, którzy pasjonują się matematyką abstrakcyjną ${ }^{18}$. Zajmuje ich wewnętrzna logika przemian samych idei. Myślę jednak, że tego typu sposób zaprzyjaźniania się z filozofią będzie bliski tylko niewielu. Obok tego nurtu istnieje i taki, dla którego ważne jest myślenie o rzeczywistości i w korelacji z rzeczywistością. Tu podkreśla się, że zawsze filozofuje ktoś i filozofuje o czymś. I to filozofowanie może się realizować na przykład poprzez badanie, jak i dlaczego właśnie takie teorie rzeczywistości formowano. To myślenie może mieć dwie realizacje, jedną nakierowaną na poznawanie świata, a drugą na samego człowieka. O co chodzi w pierwszym przypadku, skrótowo wyraził Józef Tischner pisząc na początku lat 80.: „Kiedyś filozofia rodziła się z podziwu wobec otaczającego świata (Arystoteles). A potem także z wątpienia (Kartezjusz). A teraz, na naszej ziemi, rodzi się ona z bólu" (Tischner 1982, s. 13).

Druga realizacja nawiązuje do starożytnej koncepcji filozofii, gdzie ważne były nie tylko poglądy filozofów w konkretnych kwestiach, ale i to jak ich treść wpływała na sposób rozumienia siebie i na charakter prowadzonego przez filozofa życia. Gdzie często filozofia stawała się praktyką życia, sztuką osiągania harmonii w samym sobie. To, że filozofia była w starożytności, przez wielu filozofów, traktowana jako ćwiczenie duchowe, przypomniał Europejczykom Pierre Hadot (2003) ${ }^{19}$. W kontekście bardziej współczesnym zależności te zajmują Piotra Nowaka. Uważa on, że „w takim samym stopniu ma prawo wiedzieć, o czym filozof myślał, co jakim był człowiekiem. [...] w jakim stopniu poczuwa się do odpowiedzialności za swoje myślenie" (Nowak 2014, s.164). Związki filozofii ze sposobem, w jaki filozof rozgrywa swoje życie, za ważne uważał też Józef Tischner (Tischner 1982, s. 13, 299, 303, 308). Pisał też o tym obszernie Mark Lilla w swej rozprawie Lekkomyślny umyst. Intelektualiści w polityce (2006).

Treść większości podręczników, którymi posługują się wykładający i uczący się filozofii na studiach wyższych, jest oderwania od kontekstu, w jakim powstawały i funkcjonowały konkretne poglądy czy też całe koncepcje filozoficzne. Oczywiście filozofowanie jest dialogiem z innymi - i minionymi, i aktualnie rozwijanymi - poglądami filozoficznymi. Ale jest też dialogiem, komentarzem i próbą zrozumienia spraw ważnych i bolesnych rozgrywających się w danej epoce i w danej krainie. I to zakorzenienie filozofii w sprawach i troskach człowieka powinno być bardzo istotnym kryterium oceny przydatności poszczególnych strategii nauczania.

\section{Bibliografia}

Ajdukiewicz Kazimierz. (1949). Zagadnienia i kierunki filozofii - teoria poznania, metafizyka. Warszawa: Czytelnik.

\footnotetext{
18 Ich porywa topologia, teoria mnogości i dla nich istotne są różnice między przestrzenią Hilberta i przestrzenią Banacha...

19 Takie rozumienie filozofii rozwija Pierre Hadot również w swojej następnej książce pt. Czym jest filozofia starożytna? (2000).
} 
Anzenbacher Arno. (1987). Wprowadzenie do filozofii, tłum. Zychowicz Juliusz. Kraków: Polskie Towarzystwo Teologiczne.

Bała Maciej, Jeziorska Janina, Zalewska Sabina. (2009). Pokochać mądrość. Zarys dydaktyki filozofii i etyki. Warszawa: Wydawnictwo Uniwersytetu Kardynała Stefana Wyszyńskiego.

Dymarski Zbyszek. (2001). O sztuce nauczania filozofii. W: Probucka Dorota, Olech Adam, Woźniczka Maciej. (red.). Pasja czy misja? O nauczaniu filozofii. Częstochowa: Wydawnictwo Wyższej Szkoły Pedagogicznej w Częstochowie.

Gaarder Jostein. (1995). Świat Zofii, tłum. Zimnicka Iwona. Warszawa: Jacek Santorski \& CO, Agencja Wydawnicza.

Galarowicz Jan. (1991). Na ścieżkach prawdy. Kraków: Wydawnictwo Naukowe Papieskiej Akademii Teologicznej w Krakowie.

Grudzień Józef, Jankowski Henryk, Jaroszewski Tadeusz M., Wesołowski Włodzimierz. (red.) (1970). Filozofia marksistowska. Warszawa: PWN.

Hadot Pierre. (20oo). Czym jest filozofia starożytna?, tłum. Domański Piotr. Warszawa: Fundacja Aletheia.

Hadot Pierre. (2003). Filozofia jako ćwiczenie duchowe, tłum. Domański Piotr. Warszawa: Fundacja Aletheia.

Kołakowski Leszek. (1997). Mini wykłady o maxi sprawach. T. 1. Kraków: Wydawnictwo Znak.

Kołakowski Leszek. (1999). Mini wykłady o maxi sprawach. T. 2. Kraków: Wydawnictwo Znak.

Kołakowski Leszek. (200o). Mini wykłady o maxi sprawach. T. 3. Kraków: Wydawnictwo Znak.

Kołakowski Leszek. (2004). O co pytaja nas wielcy filozofowie? Kraków: Wydawnictwo Znak.

Kołakowski Leszek. (2009). Czy Pan Bógjest szczęśliwyi inne pytania. Kraków: Wydawnictwo Znak.

Kunzmann Peter, Burkard Franz-Peter, Widmann Franz. (1999). Atlas filozofii, tłum. Markiewicz Barbara. Warszawa: Pruszyński i S-ka.

Lasocińska Estera. (2007). Kamyk filozoficzny - od starożytności do renesansu. Warszawa: Stentor.

Lilla Mark. (2006). Lekkomyślny umysł. Intelektualiści w polityce, tłum. Margański Janusz. Warszawa: Pruszyński i S-ka.

Lipman Matthew, Sharp Ann Margaret, Oscanyan Frederick S. (1996). Filozofia w szkole, tłum. Elwich Beata, Łagodzka Anna. Warszawa: Wydawnicta CODN.

Markiewicz Barbara. (1999a). Wybór tekstów. T. 1: Od filozofów jońskich do Pascala, Warszawa: WSiP.

Markiewicz Barbara. (1999b). Wybór tekstów. T. 2: Od Locke’a do Jamesa. Warszawa: WSiP.

Markiewicz Barbara. (1999c). Wybór tekstów. T. 3: Od Nietzschego do filozofii współczesnej. Warszawa: WSiP.

Martens Ekkehard, Schnädelbach Herbert. (1995). Filozofia. Podstawowe pytania, tłum. Krzemieniowa Krystyna. Warszawa: Wiedza Powszechna.

Mazur Tomasz. (2010). Kamyk filozoficzny - nowożytność. Warszawa: Stentor.

Nowak Piotr. (2014). Hodowanie Troglodytów. Warszawa: Fundacja Augusta hr. Cieszkowskiego. 
Solomon Robert C., Higgins Kathleen M. (1997). Krótka historia filozofii, tłum. SzczuckaKubisz Natalia. Warszawa: Pruszyński i S-ka.

Śleziński Krzysztof. (200o). Zarys dydaktyki filozofii. Kraków: Oficyna Wydawnicza "Impuls"

Tatarkiewicz Teresa, Tatarkiewicz Władysław. (1998). Wspomnienia. Gdańsk: MAKmed.

Tischner Józef. (1980). Polski kształt dialogu. Kraków -Warszawa -Lublin: Biblioteka "Spotkań”.

Tischner Józef. (1981). Wstęp. W: Driemer Alvin Kurs elementarny filozofii - antropologia filozoficzna, tłum. Taranczewski Paweł. Kraków: Instytut Filozofii Papieskiego Wydziału Teologicznego w Krakowie.

Tischner Józef. (1982). Myślenie według wartości. Kraków: Wydawnictwo Znak.

Węgrzecki Adam. (2002). Zarys filozofii. Kraków: Wydawnictwo Akademii Ekonomicznej w Krakowie.

Wiśniewski Ryszard. (2010-2013). Lekcja filozofii Władysława Tatarkiewicza. „Filo-sofija”, nr 13-14, s. 473-485.

Wojtysiak Jacek. (2003). Filozofia. Pochwała ciekawości. Kraków: Wydawnictwo Znak.

Wojtysiak Jacek. (2007). Filozofia i życie. Kraków: Wydawnictwo Znak.

Życiński Józef. (1985). Teizm i filozofia analityczna. t. 1. Kraków: Wydawnictwo Znak.

\title{
HOW TO TEACH PHILOSOPHY - STRATEGIES
}

\begin{abstract}
Polish media, even those ambitious ones, are not concerned about philosophical analyses or commentaries on our intellectual or political life. Moreover, there is no public demand for them, which induces us to investigate the problem further. According to the author, one of the main reasons is the way in which philosophy is taught in secondary schools and universities; it is 'sterile', i.e., deprived of any social, cultural or intellectual context. The prevailing approach is the historical (chronological) one, in which philosophical concepts are presented as intellectually sophisticated theories, very distant from everyday life. Those theories may sometimes interact with one another but hardly ever with the world.

Analyzing three strategies of teaching philosophy; namely, the historical, worldly-wise and problem-in-its-historical-context ones, the author tries to prove that a variety of approaches are possible. The main body of the article is devoted to a description of the above mentioned strategies, basing on an analysis of some most popular textbooks used in teaching philosophy.
\end{abstract}

Key words: teaching philosophy, strategies of teaching, worldly-wise philosophy, philosopher's responsibility

Zbyszek Dymarski - magister inżynier elektroniki (Politechnika Gdańska), doktor filozofii (Papieska Akademia Teologiczna w Krakowie). Zatrudniony jako adiunkt w Katedrze Kulturoznawstwa Uniwersytetu Gdańskiego. Publikacje: Dwugłos o złu. Ze studiów nad myśla Józefa Tischnera i Leszka Kołakowskiego (2009). Adres e-mail: finzd@ug.edu.pl. 